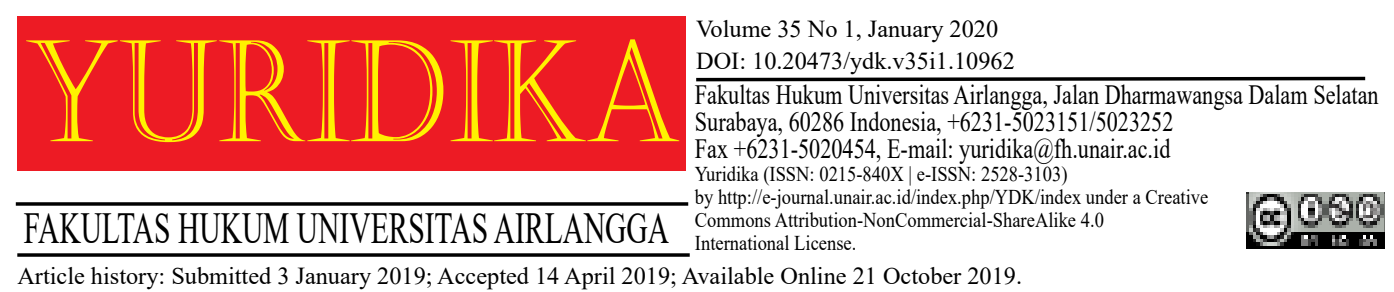

\title{
The Importance of Regulating Plastic Marine Pollution for the Protection of Indonesian Marine Environment
}

\author{
Ulya Yasmine Prisandani and Adzhana Luthfia Amanda \\ yasmineprisandani@gmail.com \\ Universitas Prasetiya Mulya
}

\begin{abstract}
The ocean and its marine resources play an important role in providing sources of livelihood to the Indonesian people. Indonesia is currently dealing with a major plastic waste problem, and this, in turn, also impacts the marine environment since the plastic waste ends up in the ocean. The issue of marine pollution is regulated under international conventions such as the MARPOL and UNCLOS, though none is specifically addressing marine plastic waste. Moreover, Indonesia has enacted several regulations to manage marine plastic waste, including Presidential Regulation Number 83 of 2018 on Marine Waste Management, and Indonesian citizens have taken an active role in reducing plastic waste. However, stricter and more specific regulations are needed as guidelines for the long-term strategy in handling marine plastic pollution in Indonesia, and proper analysis on the impact of such regulation towards the stakeholders and affected parties would be needed.

Keywords: Marine Plastic Pollution; Environmental Protection; Government Obligation.
\end{abstract}

\section{Introduction}

From 2015 to 2018, the Coordinating Minister of Maritime Affairs of the Republic of Indonesia, together with the Geospatial Information Agency (Badan Informasi Geospasial) as well as the Center of Hydrography and Oceanography (Pusat Hidrografi dan Oseanografi) of Indonesia had been collecting data and reviewing areas in Indonesia in order to prepare a National Area Data Reference (Rujukan Nasional Data Kewilayahan). This is done inter alia to ensure optimal management of the Indonesian marine resources due to the huge potential that the ocean holds, whereby further Indonesian marine resources constitutes as one of the 
strategic means to provide for the people and become the sources of livelihood ${ }^{1}$ With such potential, coastal and marine areas must be properly preserved and as such, it must be managed sustainably. The issue on how environmental rights should be a specific part of a human's right regime for various reasons have been pondered upon for years, but recently it has been increasingly linked with the sustainable development goals as adopted by all of the United Nations member states in $2015 .^{2}$

In Indonesia, the problems of plastic waste are becoming more apparent due to plastic waste built-up that clogged up rivers, ${ }^{3}$ and this eventually leads to problems in the ocean. Marine plastic waste situation has been so dire that large numbers of aquatic vertebrates worldwide are reported to die due to entanglement in plastic debris or because of ingestion of microplastics. ${ }^{4}$ Ingested plastic debris has been found to reduce stomach capacity, hinder growth, cause internal injuries, and create an intestinal blockage. ${ }^{5}$ Not only underwater creatures, but even sea birds may become entangled by certain forms of plasticware as well, such as plastic holder rings which impair the ability to fly or breathe. Further, there is an increasing number of supporting evidence that is obtained through various mechanisms which prove that marine plastic pollution causes adverse effects across successive levels of biological organization. ${ }^{6}$

In addition to hosting numerous marine organisms, the ocean also plays a major role in assimilating waste, sequestrating carbon, and help to regulate the

\footnotetext{
1 Nurdin, 'The Implementation of Vessel-Sinking Policy as an Effort to Protect Indonesian Fishery Resources and Territorial Waters'(2018) 137 IOPConference Series: Earth and Environmental Science $<$ https://iopscience.iop.org/article/10.1088/1755-1315/137/1/012038>.[1].

2 Karin Arts, 'Inclusive Development: A Human Rights Perspective' (2017) 24 Current Opinion in Environmental Sustainability.[59].

3 Eijas Ariffin, 'Indonesia's Plastic Waste Problem' (The ASEAN Post, 2018) <https:// theaseanpost.com/article/indonesias-plastic-waste-problem-0> accessed 18 December 2018.

4 Further T. Katzenberger and K. Thorpe, 'Assessing the Impact of Exposure to Microplastics in Fish: Report SC120056’ (British Environment Agency, 2015) <https://assets.publishing.service. gov.uk/government/uploads/system/uploads/attachment_data/file/411982/Assessing_the_impact_ of_exposure_to_microplastics_in_fish_report.pdf $>$ accessed 30 March 2019.

5 Michelle Sigler, 'The Effects of Plastic Pollution on Aquatic Wildlife: Current Situations and Future Solutions' (2014) 225 Water, Air, \& Soil Pollution, [2].

6 Patricia Villarrubia-Góme, 'Marine Plastic Pollution as a Planetary Boundary Threat -The Drifting Piece in the Sustainability Puzzle’ (2017) 96 Marine Policy <https://www.sciencedirect. com/science/article/pii/S0308597X17305456>.[1].
} 
climate, and these are highly important for the global environment. ${ }^{7}$ In conclusion, marine plastic waste has become a major concern due to their persistence in the ocean and negative consequences to marine organisms, leading to potential adverse effects on human health. ${ }^{8}$

The issue of marine plastic pollution in Indonesia should be handled very carefully and quickly, especially after it has been repeatedly reported in numerous news accounts and reports all over the world. In 2016, Indonesia was named as the second-largest contributor of marine plastic pollution in the world after China. ${ }^{9}$ At the end of 2018, Indonesia has gained worldwide attention due to a case concerning a dead sperm whale in the waters of Kapota Island, Wakatobi National Park, Southeast Sulawesi. ${ }^{10} 5.9$ kilograms of plastic waste was found in the stomach of the dead sperm whale was found, and such plastic waste took different forms such as plastic cups, plastic bottles, plastic bags, and others. ${ }^{11}$ It was also reported that plastic bottles, bags, sandals and a sack with more than 1,000 pieces of string were found in the whale's stomach. ${ }^{12}$ Very recently, Reuters wrote an article about how Indonesia's rivers are full of trash and plastic. ${ }^{13}$

This saddening situation may be the result of multiple factors, for example, the lack of awareness of the Indonesian citizens and businesses about proper waste management, especially those who are located near the coastal area. Marine

7 Lingjie Kong, 'Environmental Impact Assessment under the United Nations Convention on the Law of the Sea' (2011) 10 Chinese Journal of International Law.

8 Laurent C.M. Lebreton, 'River Plastic Emissions to the World's Oceans' (2017) 8 Nature Communications $<$ https://www.nature.com/articles/ncomms15611 >.[1].

9 Mawardah Nur Hanifiyani, 'Indonesia Named Second Largest Contributor of Plastic Waste' (Tempo, 2016) < https://en.tempo.co/read/743460/indonesia-named-second-largest-contributor-ofplastic-waste $>$ accessed 25 March 2019.

10 BBC News Indonesia, 'Paus Di Wakatobi Telan 115 Gelas Plastik Dan Sandal Jepit' (BBC News Indonesia, 2018) <https://www.bbc.com/indonesia/indonesia-46284830> accessed 11 December 2018 .

11 ibid.

12 Kartika Sumolang, 'Sperm Whale Washed up in Indonesia Had Plastic Bottles, Bags in Stomach' (Reuters, 2018) < https://www.reuters.com/article/us-indonesia-whale/sperm-whalewashed-up-in-indonesia-had-plastic-bottles-bags-in-stomach-idUSKCN1NP11F $>$ accessed 3 January 2018.

13 Clarence Fernandez, 'The Trash Never Stops: Indonesia Battles to Clean Up Rivers' (Reuters, 2019) < https://www.reuters.com/article/us-indonesia-environment-plastics/the-trashnever-stops-indonesia-battles-to-clean-up-rivers-idUSKCN1PH0CQ> accessed 30 March 2019. 
pollution tends to be significantly more severe in semi-enclosed marginal seas and waters that have highly populated and industrialized coastal area since the risk of contaminants from land-based sources becomes higher. ${ }^{14}$ The widespread availability of plastic for daily use has also contributed a significant amount of plastic waste being littered on land, where portions of these land waste will end up in the ocean. The Indonesian government, both regional and central, are trying to resolve the issue by enacting various laws and regulations on plastic waste, ${ }^{15}$ but serious planning and strategy will have to be employed to tackle this problem in a long term manner.

Consequently, an analysis will be conducted on the duty and responsibility of Indonesian government towards managing and handling plastic sea pollution under international law and domestic law, and the latter will examine on the extent of Indonesian laws and regulations in regulating on the government's responsibility to manage plastic sea pollution. Last but not least, the paper aims to provide a suggestion for the government in terms of drafting proper regulation and policies in the effort of reducing marine plastic waste.

\section{The Concept of Marine Plastic Pollution Under International Law}

Several international conventions have been enacted to regulate on the matter marine pollution, amongst which are the International Convention for the Prevention of Pollution from Ships 1973/1978 and the Convention on the Prevention of Marine Pollution by Dumping of Wastes and Other Matter (or also known as the London Convention on Marine Dumping, or "MARPOL"). The United States also passed several laws and regulations to rule on the issue of plastic debris to implement the provisions in the Convention, for example by

\footnotetext{
${ }^{14}$ Joint Group of Experts on the Scientific Aspects of Marine Environmental Protection, 'The Review of the Health of the Oceans, 1982 as Quoted in Lingjie Kong, "Environmental Impact Assessment under the United Nations Convention on the Law of the Sea"' (2011) 10 Chinese Journal of International Law.[653].

${ }^{15}$ For example Bali Regional Government has enacted the Bali Governor Regulation Number 97 of 2018 on the Limitation of Single-Use Plastic Product, and DKI Jakarta is currently drafting its own regulation on the matter.
} 
specifically prohibiting the disposal of plastics by any vessel in the water territory of United States. ${ }^{16}$

These conventions do not fall under the scope of this discussion since both concerns about pollution that is disposed of vessels, aircraft, and certain platforms. Furthermore, Indonesia is not a state party to the Paris Convention for the Prevention of Marine Pollution from Land-Based Sources 1974 (as amended by the Protocol on March 1986), so the provisions within do not constitute as a binding law to Indonesia. As such, the most appropriate convention to be discussed herein would be the United Nations Convention on the Law of the Sea (from now on referred to as "UNCLOS").

The UNCLOS does not exclusively regulate the matter of environment or biodiversity. However, it is the most complete and prominent treaty that regulates on all matters concerning the sea by far despite its controversies for example about the expansion of territorial sea or exclusive economic zone against what has been provided therein. UNCLOS contains one specific part which provides rules on the protection and preservation of the marine environment, namely Part XII.

Reiterating the provision in UNCLOS, it is affirmed that states are considered to be the "property owners" of the sea, and as such, own the rights and responsibilities to use and protect the sea territory under its national jurisdiction. UNCLOS in itself is created based on the principle of state responsibility and other general principles related to environmental protection, though needing other supplementary international and regional instruments to provide supporting rules and standards. The obligation to protect the marine environment is elaborated in Article 194 as follows:

"States shall take, individually or jointly as appropriate, all measures consistent with this Convention that are necessary to prevent, reduce and control pollution of the marine environment from any source, using for this purpose the best practicable means at their disposal and in accordance with their capabilities, and they shall endeavor to harmonize their policies in this connection".

${ }^{16}$ Edward A. Laws, Aquatic Pollution: An Introductory Text (John Wiley \& Sons Inc 2000).[610]. 
It is further explained that the measures taken are to prevent damage by pollution to other States and their environment ${ }^{17}$ and that the measures shall include minimization to the fullest extent the release of harmful substances from land-based sources through dumping. ${ }^{18}$

This matter has also increasingly attended to, in particular exhibited by the adoption of United Nations General Assembly Resolution 72/249 on International legally binding instrument under the United Nations Convention on the Law of the Sea on the conservation and sustainable use of marine biological diversity of areas beyond national jurisdiction, which highlights the necessity of formal negotiation for biodiversity beyond national jurisdiction matters. The result from this negotiation is expected to take the form of a treaty, which should provide a more specific conservation and governance mechanism for the protection of marine biodiversity. ${ }^{19}$

Until then, states would need to adopt a more effective and immediate measure to tackle the plastic pollution issue at hand. Moreover, it is the duty of the government to fulfill the citizen's human rights. One of the most basic human rights correlates with the right to have access to a clean environment. The right to clean environment can be inferred to originate from two more basic human rights, namely basic economic rights as well as the right to health and adequate living. The most basic human rights for clean marine environment for economic purposes can be derived from Article 1 Paragraph 2 of the International Covenant on Economic, Social, and Cultural Rights, which states the following:

"All peoples may, for their ends, freely dispose of their natural wealth and resources without prejudice to any obligations arising out of international economic co-operation, based upon the principle of mutual benefit, and international law. In no case may a people be deprived of its means of subsistence".

\footnotetext{
${ }^{17}$ Article 194 point 2 of the United Nations Convention on the Law of the Sea (UNCLOS).

${ }^{18}$ Article 194 point 3 of the United Nations Convention on the Law of the Sea (UNCLOS).

${ }^{19}$ Rachel Tiller and Elizabeth Nyman, 'Ocean Plastics and the BBNJ Treaty-Is Plastic Frightening Enough to Insert Itself into the BBNJ Treaty, or Do We Need to Wait for a Treaty of Its Own?' (2018) 8 Journal of Environmental Studies and Sciences.[412].
} 
Many of Indonesian coastal communities rely on marine resources for their source of income and living. The coastal communities have the traditional fishing right, which in this case applies to the customary fishing rights exercised by traditional inhabitants or indigenous peoples within the Indonesian jurisdiction. ${ }^{20}$

A clear definition of traditional fishing rights has not yet been provided in any international convention. Traditional fishing right commonly refers to the fishing rights that are bestowed to the permanent inhabitant of the indigenous people of the area, and it has been regarded as part of customary international law derived from State practice and fulfilling the requirement of opinion Juris. ${ }^{21}$ When the impact of plastic pollution has affected the marine biota severely, of course, as a consequence, the fulfillment of the traditional fishing rights of the Indonesian coastal communities will be interrupted.

The right to clean environment is also closely related to the right to health. The International above Covenant on Economic, Social and Cultural Rights also regulates about the right to health in Article 12, obliging State Parties to recognize the right to the enjoyment of the highest attainable standard of physical and mental health, as well as to take steps to achieve the full realization of such right. It is even stated that the improvement of environmental aspects and industrial hygiene forms one part of the measures that can be taken by the States, ${ }^{22}$ and as such this has a very close connection to the case of marine pollution in Indonesia.

\section{Marine Plastic Pollution under Indonesian Law}

As a sovereign state, Indonesia has the authority to regulate its internal matters, including management and handling of the marine pollution problem that is inevitable due to its geographical background of being surrounded by seas. The

\footnotetext{
${ }^{20}$ There are two types of traditional fishing rights, namely the customary fishing rights as well as the traditional fishing rights granted by one State to nationals of another State outside of their own jurisdiction.

${ }^{21}$ Dysi Polite, 'Traditional Fishing Rights: Analysis of State Practice' (2013) 5 Australian Journal of Maritime \& Ocean Affairs.[121].

${ }^{22}$ Article 12 point 2 (b) of the International Covenant on Economic, Social and Cultural Rights.
} 
Constitution clearly states that the waters and natural resources within Indonesian jurisdiction shall be under the power of the State, and shall be used for the greatest benefit of the people. ${ }^{23}$ The Constitution also stipulates the citizens' right to live in physical and spiritual prosperity, as well as to have a home and to enjoy a good and healthy environment, and lastly to have the right to obtain medical care. ${ }^{24}$ This is in line with what has been regulated under the International Covenant on Economic, Social and Cultural Rights.

The definition of marine plastic pollution is not directly and expressly stated under any Indonesian law and regulation. Law Number 32 of 2009 on Environmental Protection and Management does not provide any specific definition of marine pollution, and its closest linked provision would surround the concept of waste in general. The Environmental Protection and Management Law only defines waste as the residue of a business or activity, and not stating plastic waste to specifically fall under this category, albeit regulating hazardous and toxic waste. ${ }^{25}$ It is further stated that waste dumping should obey the applicable regulations regarding the quantity, concentration, time, and location, as well as other specific requirements and the specific environmental media. ${ }^{26}$

However, relevant definitions are present in Presidential Regulation Number 83 of 2018 on Marine Waste Management. The term 'Marine Pollution' is defined as the "entrance of any organism, substance, energy, and other components into the ocean ecosystem that is caused by human activities that results in a seawater quality standard that is lower than the set limit". ${ }^{27}$ Marine waste herein is defined as the remaining solid byproduct of daily human activities and/or natural processes that originate from the land, body of water, and coast that flow to the sea, or even

\footnotetext{
${ }^{23}$ Article 33 of the 1945 Constitution of Republic of Indonesia.

${ }^{24}$ Article $28 \mathrm{H}$ of the 1945 Constitution of Republic of Indonesia.

${ }^{25}$ See Article 1 Paragraph 20 and 21 of Law Number 32 of 2009 on Environmental Protection and Management.

${ }^{26}$ Article 1 Paragraph 24 of Law Number 32 of 2009 on Environmental Protection and Management.

${ }^{27}$ Article 1 Paragraph (1) of Presidential Regulation Number 83 of 2018 on Marine Waste Management.
} 
originate from activities carried out in the sea, ${ }^{28}$ where Article 1 Paragraph (4) of the Regulation defines plastic waste as waste that contains polymer compound. In conclusion, plastic waste falls under the category of sea pollution under the Regulation. ${ }^{29}$ With this, it is clear that the concept of plastic waste is recognized and interpreted under Indonesian domestic regulation.

In 2016, Indonesia tried to reduce plastic use by introducing a US\$0.02 tax on single-use plastic bags. ${ }^{30}$ Further, the Indonesian government has stipulated specific measures which are provided under Presidential Regulation Number 83 of 2018 on Marine Waste Management, namely through the direction for creating a National Action Plan on Marine Waste Management $2018-2025^{31}$ as well as a National Coordination Team for Marine Waste Management that reports directly to the President. ${ }^{32}$ The National Action Plan takes the form of a planning document that provides strategic direction for ministries/agencies and references for the community and business actors to accelerate the handling of marine waste starting from 2018 to $2025 .{ }^{33}$ Further, the strategies of the National Action Plan would include national movement to increase awareness of stakeholders, management of land-based waste, waste management on the coast of the sea, research and development as well as a funding mechanism, institutional strengthening, supervision, and law enforcement. ${ }^{34}$

Local governments have also participated actively in the effort of reducing plastic land waste, which in turn will also reduce plastic marine pollution. The local government of Bali had been the first to enact Governor Regulation Number 97 of 2018 on the Limitation of Single-Use Plastic Product which stipulates that plastic

${ }^{28}$ Article 1 Paragraph (2) and (3) of Presidential Regulation Number 83 of 2018 on Marine Waste Management.

29 Article 1 Paragraph (4) of the Regulation defines plastic waste as "waste that contains polymer compound". As such, it is regard to have fulfilled the definition provided in Paragraph (1) since there is no further specification therein.

${ }^{30}$ Eijas Ariffin (n 3).Loc.Cit.

${ }^{31}$ Article 2 of Presidential Regulation Number 83 of 2018 on Marine Waste Management.

32 Article 4 of Presidential Regulation Number 83 of 2018 on Marine Waste Management.

33 Article 2 Paragraph (2) of Presidential Regulation Number 83 of 2018 on Marine Waste Management.

${ }^{34}$ Article 2 Paragraph (3) of Presidential Regulation Number 83 of 2018 on Marine Waste Management. 
bags, polystyrene (commonly known as styrofoam) as well as plastic straws are banned, and shall be replaced with other alternatives. ${ }^{35}$ Administrative sanctions are also stated for any institution or businesses that still use single-use plastic products for daily activities. ${ }^{36}$

Not only the government, but it is also interesting to see that the Indonesian citizens themselves have taken steps to reduce plastic waste, especially those of single-use plastic products that are used daily. Communities participation are proven to have an impact on a better decision-making process for the government, ${ }^{37}$ and campaigns have been conducted to eliminate the use of plastic straws. These campaigns advocate for replacing single-use plastic straws with other environmentally friendly alternatives such as reusable stainless or glass straws.

Moreover, Law Number 32 the Year 2009 on Environmental Protection and Management gives communities the right and access to participate by submitting suggestions, objections, and making complaints to the government. ${ }^{38}$ Most importantly, these communities are direct participants and actors of the enacted laws and regulations, and as such increasing community participation in reducing plastic waste is inseparable from the effort to eliminate plastic waste for better Indonesian marine environment.

Further assessment needs to be conducted on whether Indonesia has carried out its duty to fulfill about treating marine waste plastic pollution under its National Action Plan as mandated under the Presidential Regulation Number 83 of 2018 on Marine Waste Management. ${ }^{39}$ However, steps have been taken to reduce

${ }^{35}$ Article 4 Paragraph (1) of Bali Governor Regulation Number 97 of 2018 on the Limitation of Single-Use Plastic Product.

${ }^{36}$ Article 22 of Bali Governor Regulation Number 97 of 2018 on the Limitation of Single-Use Plastic Product.

37 Ciara Fitzgerald, [et.,al.] 'Citizen Participation in Decision-Making: Can One Make a Difference?' (2016) 25 Journal of Decision Systems <https://www.tandfonline.com/doi/full/10.108 0/12460125.2016.1187395>.[257-258].

38 Law Number 32 of 2009 on Environmental Protection and Management also states that communities have equal rights and opportunities to have an active role in environmental protection and management; See also Chapter V of Bali Governor Regulation Number 97 of 2018 on the Limitation of Single-Use Plastic Product on Community Participation.

39 See the Appendix of Presidential Regulation Number 83 of 2018 on Marine Waste Management on the detailed list of the programs listed under the National Action Plan. 
plastic waste in general, and the Indonesian government's effort, in that case, is commendable. More specifically, regulation must be drafted and enacted aptly to be able to tackle the issue effectively.

\section{Regulating Plastic Use for Better Marine Environment}

At the United Nations' first Ocean Conference June 2018, which focused on the sustainable use of the oceans, seas and marine resources, Indonesia pledged to reduce plastic debris by $70 \%$ by $2025 .{ }^{40}$ To achieve this target, the government said that it would contribute US\$1 billion annually to the effort. Indonesia is not alone in the battle of reducing marine plastic waste as several other countries have also adopted regulations which mandate for the limitation of restriction of plastic use for marine environment protection. To name a few, Taiwan has adopted policies for restriction and compulsory garbage sorting while South Korea has a fishing gear buyback program that intends to provide a solution for marine litter management challenges. ${ }^{41}$

For now, the government of Indonesia first needs to map out the proper solution for dealing with plastic, for example, through the reduction of use as well as encouraging recycling initiatives. The government of Indonesia has obliged producers to conduct recycling process under Government Regulation Number 81 of 2012 on the Management of Household Waste and Similar Waste Types, ${ }^{42}$ and recycling methods including the mechanical recycling method that converts PET, HDPE, LDPE, and PP plastic waste into reusable plastic pellets have been implemented in Indonesia. ${ }^{43}$

The existing regulations can help to reduce plastic use by businesses and communities; however, stricter rules may be needed to cause a deterrent effect

\footnotetext{
${ }^{40}$ Andi Hajramurni, 'Indonesia Aims to Tackle Plastic Waste' (Jakarta Post, 2018) <https:// www.thejakartapost.com/news/2018/03/18/indonesia-aims-to-tackle-plastic-waste.html $>$ accessed 30 March 2019.

${ }^{41}$ Melanie Bergmann, [et.,al.], Marine Anthropogenic Litter (Springer).[417].

${ }^{42}$ Regulated specifically under Article 13 of Government Regulation Number 81 of 2012 on the Management of Household Waste and Similar Waste Types.

${ }^{43}$ Hin Chandara, [et.,al.], 'Plastic Recycling in Indonesia by Converting Plastic Wastes (PET, HDPE, LDPE, and PP) into Plastic Pellets' (2015) 1 ASEAN Journal of Systems Engineering.[66].
} 
in plastic polluters. Sanctions and disincentives may be imposed for violators. Comparable sanctions have been carried for industries with harmful liquid waste mismanagement in Banten, ${ }^{44}$ and it may be beneficial to impose similar sanctions for plastic polluters to reduce the level of plastic waste that exist in Indonesia. Additionally, community participation that already has been regulated generally in various provisions ${ }^{45}$ may also be further specified.

In determining the right sanctions and disincentives, or on the contrary, reward, and incentives, the relevant governmental organization can conduct the Cost and Benefit Analysis ${ }^{46}$ before enacting the law to see the benefits and costs for each of the parties that will be affected by the regulation. After all, marine plastic waste is a multi-layered problem that affects almost all members of society. Special attention may also be paid to the scavenger communities which rely on the use of plastic products as their source of living since protests against the antiplastic regulation have been expressed due to jeopardizing the livelihood of these scavenger populations. ${ }^{47}$

\section{Conclusion}

The Indonesian government has already formulated a National Action Plan based on the obligation mandated under Presidential Regulation Number 83 of 2018 on Marine Waste Management, and as such, must implement it fully and in the most favorable way for the citizen about reducing marine plastic waste that pollutes Indonesian water bodies. The government is also obliged to fulfill the general environmental protection provided under Law Number 32 of 2009 on

${ }^{44}$ Achmad Irfan, ‘418 Industri Di Tangerang Disanksi Terkait Pencemaran Limbah' (Antara News, 2019) <https://banten.antaranews.com/berita/37601/418-industri-di-tangerang-disanksi-terkait-pencemaran-limbah> accessed 31 March 2019.

${ }^{45}$ Such as in Chapter VII of Government Regulation Number 81 of 2012 on the Management of Household Waste and Similar Waste Types and Chapter XI of Law Number 32 of 2009 on Environmental Protection and Management.

${ }^{46}$ One of the references for Cost and Benefit Analysis is issued by the National Development Planning Agency (Badan Perencanaan Pembangunan Nasional).

47 Ratna Puspita, 'Ikatan Pemulung Keberatan Larangan Penggunaan Plastik' (Republika, 2019) < https://nasional.republika.co.id/berita/nasional/umum/19/01/15/pld5lw428-ikatan-pemulung-keberatan-larangan-penggunaan-plastik> accessed 31 March 2019. 
Environmental Protection and Management, such as carrying out its supervisory function and issuing sanctions for violators.

Nevertheless, a stricter and more detailed set of regulation on the matter of marine plastic waste may help provide a stronger legal basis to reduce the harm to the marine environment that is caused by plastic waste pollution. Since the issue concerns many different stakeholders and different types of entities, a thorough analysis needs to be conducted, and this can be done through inter alia carrying out a Cost and Benefit Analysis. Further, the government must also take into account parties that will be unfavorably affected by the plastic reduction regulation, for example, the scavengers communities.

\section{Bibliography}

Achmad Irfan, '418 Industri Di Tangerang Disanksi Terkait Pencemaran Limbah' (Antara News, 2019) <https://banten.antaranews.com/berita/37601/418industri-di-tangerang-disanksi-terkait-pencemaran-limbah $>$ accessed 31 March 2019.

Andi Hajramurni, 'Indonesia Aims to Tackle Plastic Waste' (Jakarta Post, 2018) $<$ https://www.thejakartapost.com/news/2018/03/18/indonesia-aims-totackle-plastic-waste.html> accessed 30 March 2019.

Bali Governor Regulation Number 97 of 2018 on the Limitation of Single-Use Plastic Product.

BBC News Indonesia, 'Paus Di Wakatobi Telan 115 Gelas Plastik Dan Sandal Jepit' (BBC News Indonesia, 2018) <https://www.bbc.com/indonesia/ indonesia-46284830> accessed 11 December 2018.

Ciara Fitzgerald, [et.,al.], 'Citizen Participation in Decision-Making: Can One Make a Difference?' (2016) 25 Journal of Decision Systems $<$ https://www. tandfonline.com/doi/full/10.1080/12460125.2016.1187395>.

Clarence Fernandez, 'The Trash Never Stops: Indonesia Battles to Clean Up Rivers' (Reuters, 2019) <https://www.reuters.com/article/us-indonesiaenvironment-plastics/the-trash-never-stops-indonesia-battles-to-clean-uprivers-idUSKCN1PH0CQ> accessed 30 March 2019.

Dysi Polite, 'Traditional Fishing Rights: Analysis of State Practice' (2013) 5 Australian Journal of Maritime \& Ocean Affairs. 
Edward A. Laws, Aquatic Pollution: An Introductory Text (John Wiley \& Sons Inc 2000).

Eijas Ariffin, 'Indonesia's Plastic Waste Problem' (The ASEAN Post, 2018) <https:// theaseanpost.com/article/indonesias-plastic-waste-problem- $0>$ accessed 18 December 2018.

Further T. Katzenberger and K. Thorpe, 'Assessing the Impact of Exposure to Microplastics in Fish: Report SC120056' (British Environment Agency, 2015) <https://assets.publishing.service.gov.uk/government/uploads/system/ uploads/attachment_data/file/411982/Assessing_the_impact_of_exposure_ to_microplastics_in_fish_report.pdf $>$ accessed 30 March 2019.

Government Regulation Number 81 of 2012 on the Management of Household Waste and Similar Waste Types.

Hin Chandara, [et.,al.], 'Plastic Recycling in Indonesia by Converting Plastic Wastes (PET, HDPE, LDPE, and PP) into Plastic Pellets' (2015) 1 ASEAN Journal of Systems Engineering.

Joint Group of Experts on the Scientific Aspects of Marine Environmental Protection, 'The Review of the Health of the Oceans, 1982 as Quoted in Lingjie Kong, "Environmental Impact Assessment under the United Nations Convention on the Law of the Sea"' (2011) 10 Chinese Journal of International Law.

Karin Arts, 'Inclusive Development: A Human Rights Perspective' (2017) 24 Current Opinion in Environmental Sustainability.

Kartika Sumolang, 'Sperm Whale Washed up in Indonesia Had Plastic Bottles, Bags in Stomach' (Reuters, 2018) <https://www.reuters.com/article/us-indonesiawhale/sperm-whale-washed-up-in-indonesia-had-plastic-bottles-bags-instomach-idUSKCN1NP11F> accessed 3 January 2018.

Laurent C.M. Lebreton, 'River Plastic Emissions to the World's Oceans' (2017) 8 Nature Communications <https://www.nature.com/articles/ncomms15611>.

Law Number 32 of 2009 on Environmental Protection and Management.

Lingjie Kong, 'Environmental Impact Assessment under the United Nations Convention on the Law of the Sea' (2011) 10 Chinese Journal of International Law.

Mawardah Nur Hanifiyani, 'Indonesia Named Second Largest Contributor of Plastic Waste' (Tempo, 2016) <https://en.tempo.co/read/743460/indonesia-namedsecond-largest-contributor-of-plastic-waste> accessed 25 March 2019. 
Melanie Bergmann,[et.,al.], Marine Anthropogenic Litter (Springer).

Michelle Sigler, 'The Effects of Plastic Pollution on Aquatic Wildlife: Current Situations and Future Solutions', (2014), 225 Water, Air, \& Soil Pollution.

Nurdin, 'The Implementation of Vessel-Sinking Policy as an Effort to Protect Indonesian Fishery Resources and Territorial Waters' (2018) 137 IOP Conference Series: Earth and Environmental Science $<$ https://iopscience.iop. org/article/10.1088/1755-1315/137/1/012038>.

Patricia Villarrubia-Góme, 'Marine Plastic Pollution as a Planetary Boundary ThreatThe Drifting Piece in the Sustainability Puzzle'(2017)96 MarinePolicy $<$ https:// www.sciencedirect.com/science/article/pii/S0308597X17305456>.

Presidential Regulation Number 83 of 2018 on Marine Waste Management.

Rachel Tiller and Elizabeth Nyman, 'Ocean Plastics and the BBNJ Treaty-Is Plastic Frightening Enough to Insert Itself into the BBNJ Treaty, or Do We Need to Wait for a Treaty of Its Own?' (2018) 8 Journal of Environmental Studies and Sciences.

Ratna Puspita, 'Ikatan Pemulung Keberatan Larangan Penggunaan Plastik'(Republika, 2019)<https://nasional.republika.co.id/berita/nasional/umum/19/01/15/ pld5lw428-ikatan-pemulung-keberatan-larangan-penggunaan-plastik> accessed 31 March 2019.

HOW TO CITE: Ulya Yasmine Prisandani and Adzhana Luthfia Amanda, 'The Importance of Regulating Plastic Marine Pollution for the Protection of Indonesian Marine Environment' (2020) 35 Yuridika. 
--This page is intentionally left blank-- 